\title{
Government of Indonesia's Battling Strategy to Cope With Pseudo-Cooperatives
}

\author{
Nining I Soesilo
}

\begin{abstract}
By contesting the political spectrum versus the economic side of regulation, it is found that the Indonesian cooperative's performance is influenced more by the first approach. As Golkar's electoral vehicle to protect its ruling party's majority vote, the cooperative apex organization (Dekopin) became a parastatal. As a 'bureaucratic capitalist' with state budget support, Dekopin's 'holdup problem' creates the 'subsidy mentality' and increasing corruption perception that stimulated the formation of pseudo-cooperatives. A bottom-up petition to remove Dekopin's parastatal status failed. By calibrating the 2012-2014 panel data, the pseudocooperatives decrease when active cooperatives increase. From the 2015 cross-section exercise, pseudocooperatives' number rises along with the growing population. External funding to cooperatives is used as a means to spend it on leisure. Many islands show different tendencies of pseudo-cooperatives' creation. In 2016, a government's economic strategy to create healthy cooperatives was started by closing down 32,778 pseudo-cooperatives. This process continued until 2019.
\end{abstract}

Keywords: cooperative enterprises, cross-sectional models, finance in urban and rural economies, relation of economics to social values

\begin{abstract}
Abstrak
Dengan mengkontraskan spektrum politik dengan sisi ekonomi dari peraturan, ditemukan bahwa kinerja koperasi Indonesia lebih dipengarubi oleh pendekatan pertama. Sebagai kendaraan politik Golkar untuk melindungi suaranya yang mayoritas sebagai partai berkuasa, organisasi puncak koperasi (Dekopin) dijadikan sebagai Lembaga Non-Struktural (LNS). Dengan perannya sebagai 'kapitalis birokrati's dengan dukungan APBN, maka Dekopin telah menjadi ajang perebutan kekuasaan internal dan menciptakan 'mentalitas subsidi' serta meningkatkan persepsi korupsi yang merangsang pembentukan koperasi semu di tanah air. Petisi dari bawah ke atas untuk menghapusstatus LNS ini gagal. Dengan mengkalibrasi data panel 2012-2014, maka terlihat bahwa koperasi semu berkurang ketika jumlah koperasi yang aktif meningkat. Dari hasil uji ekonometrika 'cross-section' tahun 2015, jumlah koperasi semu ini terlihat meningkat seiring dengan pertumbuhan penduduk. Pendanaan eksternal untuk koperasi ternyata digunakan sebagai sarana untuk membiayai biaya perjalanan. Banyak pulau menunjukkan kecenderungan penciptaan koperasi semu yang berbeda. Pada tahun 2016, strategi ekonomi pemerintah untuk menciptakan koperasi yang sehat dimulai dengan menutup 32.778 koperasi semu. Proses ini berlanjut hingga tahun 2019.
\end{abstract}

Kata Kunci: perusahaan koperasi, model lintas-bagian, keuangan dalam ekonomi perkotaan dan pedesaan, hubungan ekonomi dengan nilai sosial

JEL Classification: G21

\section{How to Cite:}

Soesilo, N. I. (2020). Government of Indonesia's Battling Strategy to Cope with Pseudo-Cooperatives. Signifikan: Jurnal Ilmu Ekonomi, 9(2), 219-240. doi: http://doi.org/10.15408/sjie.v9i2.15547. 


\section{Introduction}

... the present approach to cooperatives is different. They are being pampered, which is not pedagogically sound, because they are not stimulated to be' self-starting. Hence, although at present there is a larger number of cooperatives, the quality of most of them is not what it should be (Subroto, 1998)

Based on the citation mentioned above, the general notion is that Indonesia's cooperative movement has yet to grip and make its impact felt. Despite government efforts to give many incentives, cooperatives have also been rewarded with essential benefits and peculiarities in several market segments, pouring funding and boosting the significant increase of cooperatives' registration. Unfortunately, it only increases the number of pseudocooperatives. The poor quality of the Indonesian cooperatives, according to Subroto, is due to the pampered policy (Subroto, 1998) that produces the 'subsidy mentality' (Kabner, 2009, bin-Joharie, 1988) and induce downgraded economic contribution. The cooperatives' policy output is the result of two pairs of contests. First; the traditional LeftRight characterization of the political spectrum (Soper, 1999; Bobbio, 1997). Second, the economic theory of regulation consists of the interaction of the supply of governmentbestowed benefits and the demand for those benefits by consumers and firms (Stigler, 1971; Pirie, 2019).

Former president Soeharto during his term from 1966 to 2008, consolidated activism through cooperatives with government activities (Setiyono \& McLeod, 2010) by incorporating Golkar as the ruling party's activities. In his early years of the New Order, the priority policy was to develop rural areas due to the location of the majority of Indonesia's population to earn a living. Hence, forming the agricultural cooperative was a must with a top-down approach. No wonder that the number of state-run cooperatives multiplied. Primarily the agricultural or 'village cooperatives' (KUD) and 'village enterprises' (BUUD). There was also the 'Mass Guidance' (BIMAS) and 'Mass Intensification' (INMAS) or agricultural intensification (Subroto, 1998). Giving state budget to cooperatives that have the affiliation with the ruling party (Golkar), was based on political consideration (Setiyono \& McLeod, 2010) in the form of external funding that creates 'clientelism' (Hicken, 2011; Merton, 1968, as cited by Thomas \& Hangula, 2011).

Before President Soeharto ruled Indonesia (1965-1998), Soekarno was the first president from 1945-1965. Soekarno was supported by Sjahrir, a democratic socialist who recognized the danger of communism, and M. Hatta, a practical. 'workmanlike cooperative economist,' with advanced capability (US Government Printing Office, 1967). Hatta can complement Soekarno about the economic side. Marx inspired Soekarno, Hatta, and Sjahrir, but they are not communists (Susilo \& Pratamasari, 2018). Soekarno believed that the indigenous peoples and local communities could be an agent for change. However, they might have tiny steps, as seen in Soekarno's proletarianism concept of 'Marheinism,' or 'Marxism adjusted to Indonesia" (Henderson, 1970). It was later used as a method of law, a theory, and an ideology (Bobbio, 1997). Previously, Hatta went to Denmark and other Scandinavian countries to absorb about the cooperative development in which the bulk of its inhabitants recorded as cooperatives' members (Noer, 2012; Susilo \& Pratamasari, 2018). Combining the spirit 
of 'think globally, act locally' (Watanabe, 2018; Dunlap, 2018) and stimulating the small people but in massive numbers all over the country will help create more meaning to the Indonesian independence. It is similar to the 'Small is beautiful' spirit (Schumacher, 1973). Both Soekarno and Hatta, as President and vice president, agreed with this concept through cooperatives' vision. Through politics, Hatta, as the father of Indonesian Cooperatives initiated Article 33 of the 1945 Constitution about the economy, that shall be shaped as a mutual undertaking based upon the family system's guidelines. Because the "politics matters" Hatta saw cooperative was essential and the massive mobilization was necessary for making cooperative movement respectable in some ways.

In Indonesia, cooperative mobilization was initiated by the establishment of SOKRI (Central Organization of Indonesian People's Cooperative) as national cooperative apex organization on July 12, 1947, that became the national cooperative day. The names were then transformed six times to finally modified into the Indonesia Cooperative Council (DEKOPIN) in 1977 up to present (Putra, 2016). The creation and design of different forms of organization and contracting in cooperatives usually was the result of the minimization of transaction costs (Torgerson et al., 1998). Wright (2011) argued that the optimal aggressive arrangement of power for forming the normative principles of democratic egalitarianism, such as in cooperatives, is parallel with superior democratic social control over the power of the state and the market. In the 'hyphenated society,' the 'perpetual conflicts' exists between three persisting forces consist of the demand for economic profitability, the taxation obligations of the modern states, and the right of the citizen to welfare facility (Marshall as cited in Turner, 1986). In 1956, President Soekarno began to pave the way toward guided democracy. He introduced the pillars of 'Nasakom' or the Nationalist, Religion, and Communist (Anwar, 2002; Matanasi, 2017).

Hatta refused Soekarno's idea and later stepped down because Sukarno's decision would make the state power is superior to social control. From this point in history, the Left-Right politicalspectrum was influential. 'Marhaenist' or 'Marxism adjusted to Indonesia' (Henderson, 1970) philosophy became discredited under the Soeharto regime, albeit countered by efforts in June 1967 to re-emphasize its association with the official state philosophy of Pancasila, when the secular versus the Islamic state had emerged. In 2020, during President Jokowi era, the winning party PDIP as a new form of PNI party try to redefine their doctrine of "Trisila" as the essence of Pancasila with the Pancasila Ideology Bow Directive as a proposed new Law. It reaps a lot of controversy during the COVID 19 pandemic because the public perceives this as a modern revival of Communism. 'Trisila' means 'Marhenism is the belief in God Almighty, Socio-Nationalism, and Socio-Democracy' (Henderson, 1970). Under the Soeharto era in 1966-1988, the New Order underlined nationalism as another new opposing pole against Marxism. Hence Marhaenist philosophy became discredited under the Soeharto regime. (Henderson, 1970).

Political mobilization from the top as a "bureaucratic polity" creates stability (Jackson as cited in Kuntowijoyo 1987), to display and generates a perception that the initial idea of cooperative is the bureaucracy and not from the 'self-starting' (Subroto,1998). This topdown approach is the logic behind president Soeharto's decision to give the state budget to 
Dekopin. The cooperatives were designed as an electoral vehicle, as consolidated activism that can be maintained and preserved to protect a clear majority of the vote by reducing the number of political parties approved to contest elections for seats in the parliament (DPR) (Setyono \& McLeod, 2010).

President Soeharto changed Dekopin from a self-starting organization into a parastatal. Hence, the position of the state is above the cooperative as a social movement. It induced wicked influence problems (Merton, 1968, as cited by Thomas \& Hangula, 2011; Muller, 2006 and Hopkin, 2006) called 'clientelism.' Merton (1968) elaborated 'clientelism' as "humanizing and personalizing all manner of assistance to those in need" or "instrumental friendship" (Scott, 1972 in Hicken, 2011) or refers to "dyadic" alliances where clients have a close personal relationship with the patron (Hicken, 2011). The government becomes the political principal. Dekopin becomes the agent. The government's external capital to Dekopin and cooperatives has been used as a "clientelistic vehicle" similar to an exclusive right to Bumiputra in Malaysia (Kabner, 2009). The same encouragement from the state for cooperatives in most developing countries is no longer what it used to be. Still, the state continues in the perpetuation of the perverse mechanism of control, supervision, and dependency that creates a hindrance to capacity building (Pinto, 2011).

Actually, 'the past is never dead; it's not even past (Faulknerian assumption).' The bigheadedness to tell the past 'as it was' is a biased contemporary affair. The 'genealogies and narratives with causalities and meanings' only emerge by looking at the present 'through some very long and very wide lenses' (Somers, 2008). The 'perpetual conflicts' in the 'hyphenated society,' during Soekarno Hatta has also happened in Dekopin. It worsened since this organization becomes a parastatal during President Soeharto's era enjoying the luxury of the annual state budget.

Dekopin is currently responsible for the training of secondary and primary cooperatives with no ample sensitization and education methodologies and accountability. There is an interaction of the supply of government-bestowed benefits from cooperative regulation with those who demand the benefits (Stigler 1971, Pirie, 2019) by Dekopin and grassroots cooperatives. The 2009 UN guidelines of cooperation between the UN and the Business Sector stated that "Neither party has the power to bind the other party or to contract in the name of the other party or create a liability against the other in any manner whatsoever" (UN, 2009). However, the creation of liability is still alive in the Indonesian cooperatives. The 'subsidy mentality' made cooperatives as the government's liability.

State budget grants changed Dekopin into a "bureaucratic capitalists" (Robison as cited by Kuntowijoyo, 1987) with an immediate stronger stance vis-à-vis the pre-existing or the' self-starting bottom-up primary cooperatives. The 'holdup problem' occurs both in Dekopin and in primary cooperatives all over Indonesia due to a contractual relationship based on a specific assets scheme pursues to exploit the other faction's weakness (Royer, 1999). No wonder that conflicts are rampant at the top level of the cooperative movement (Dekopin), especially since Dekopin received the State Budget. In August 2006, Sri Eddy Swasono won the lawsuit against Adi Sasono, and Adi Sasono also brawled with 
Nurdin Halid concerning Dekopin's leadership (Abdurrahman, 2019). Dekopin's leader Nurdin Halid, a former corruption jailbird, was re-elected in 2019 for four consecutive terms incessantly even while he was still in prison and will lead Dekopin in 2019-2024 (Abdurrahman, 2019) albeit there was an issue of money politics in Nurdin Halid's election as Dekopin's chairman (CSIS, 1999). In 2004-2009, Nurdin Halid was arrested in the case of illegal sugar imports.

Albeit Nurdin Halid's lousy image, he has been chairing Dekopin four terms in a row (Johan, 2002), albeit violating the Dekopin Statutes and by-laws itself. Golkar is the party where Nurdin Halid also concurrently holds a position as the Party Daily Chairman. He was an acting chairman of the Golkar Party when Setya Novanto, the general chairman of the Golkar Party, went to prison after found guilty due to convicted in the procurement of electronic-ID corruption case. Nurdin Halid is also a former corruptor who was jailed for a corruption case.

Figure 1. Indonesian Cooperatives 2012-2019 with exceptional year in 2015

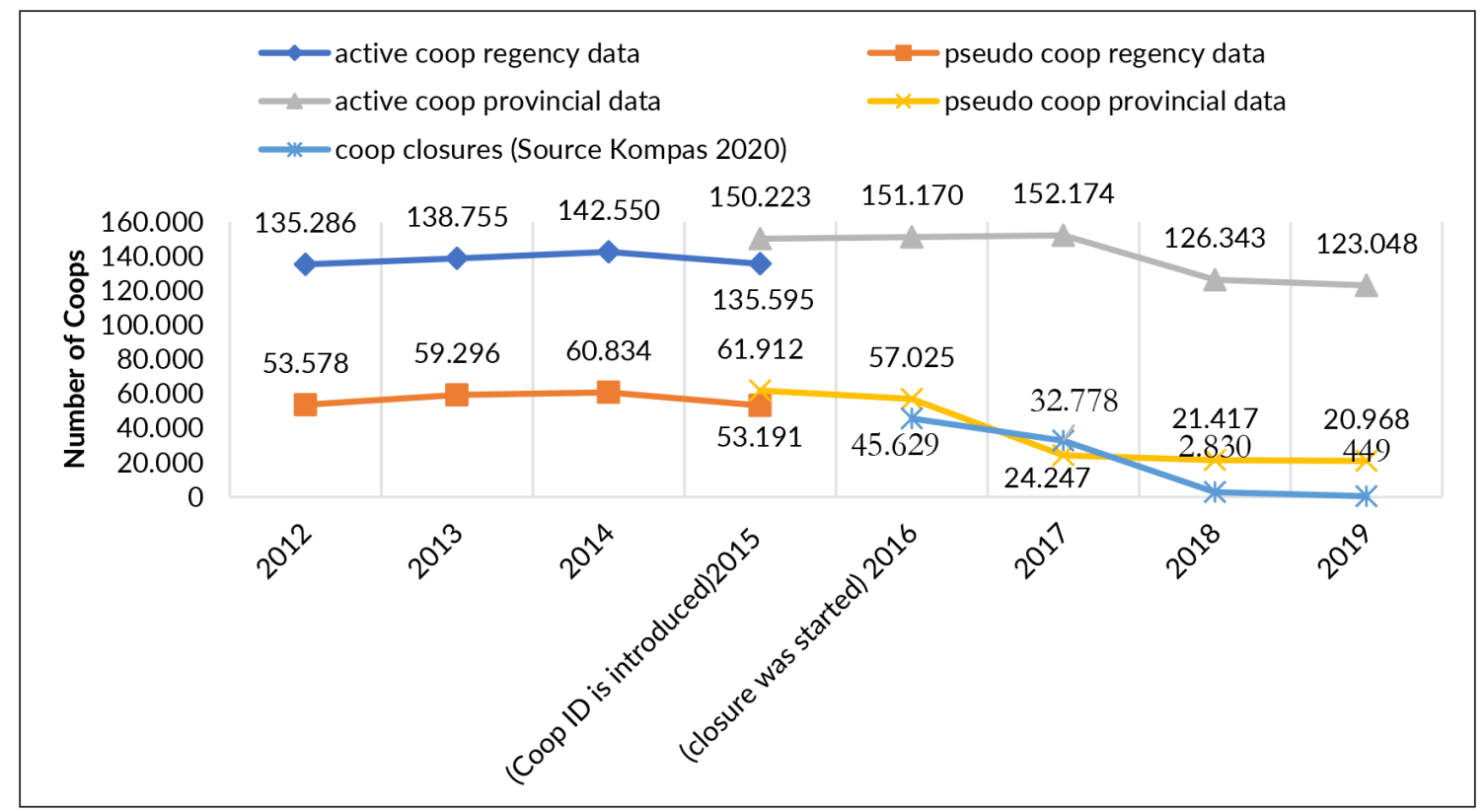

This research tries to fill the gap between the economic theories of regulation (with supply and demand of rule) with the political spectrum of the traditional Left-Right characterization about cooperatives in Indonesia by investigating the cooperatives' data from 2012-2019. It is done by scrutinizing the role of Dekopin as the cooperatives' apex organization and performance of pseudo-cooperative firms at the regency level in Indonesia. The Indonesia government's battling strategy to cope with pseudo cooperatives was started in 2015 to create a better economic performance amid the domination of the political spectrum. By finding more evidence through empirical analysis using a mixed qualitative and quantitative approach, it is hoped the execution of the strategy could be execution. This calibration is similar to 'a bricolage of history, political science, economics, and sociology (Somers, 2008) to bridge and deliver a general connection across the extensive collection 
of academic disciplines. Albeit as a problem-driven study, this research suffers from brittle philosophical anchorages due to the eclectic nature of entrepreneurship theory (Verheul et al., 2001), a new problem-solving technique would be found.

\section{Methods}

There are three steps in this research. The first and second steps are quantitative exercises. First, by applying fixed effect panel data from 2012-2014 by using the uncleaned data, Second using the robust regression using the 2015 cross-section aggregate data exercise from regencies and cities all over the country to reveal the cooperatives' misconducts. The particular year 2015 is the year when battling strategy was started by cleansing the data, hence a more detailed elaboration of this year's will be applied. The more recent data from 2016 to 2019 is analyzed by descriptive elaboration due to unreliability of the data. The third, using an in-depth interview with decision-makers and cooperatives experts and practitioners. The primary data is collected through in-depth discussions with some respondents mentioned above to calibrate the findings. Some respondents for detailed analysis consist of the former Minister of Cooperatives and SME; the former Secretary-General from the Ministry of Cooperatives and SME; the Practitioner and the Head of Kosakti Coop; the SecretaryGeneral of Indonesian Credit Union Association; a cooperative expert from the Ministry of Cooperative and SME; the leader of Kopkun Institute; a leader of the rural electrification and the leader of the Sahara cooperative.

Tabel 1. The growth of Active and Pseudo Cooperatives as well as Corruption Perception in Indonesia 2012-2019.

\begin{tabular}{|c|c|c|c|c|c|c|}
\hline \multirow{3}{*}{ Year \& Growth } & \multicolumn{2}{|c|}{ (2) } & \multicolumn{2}{|c|}{ (3) } & \multirow{3}{*}{$\begin{array}{c}\text { (4) } \\
\text { Corruption } \\
\text { Perception } \\
\text { Index (max } \\
\text { 100) From } \\
\text { TI }\end{array}$} & \multirow{3}{*}{ 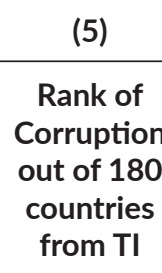 } \\
\hline & \multicolumn{2}{|c|}{$\begin{array}{l}\text { Active Coop Based } \\
\text { on Data from }\end{array}$} & \multicolumn{2}{|c|}{$\begin{array}{l}\text { Pseudo Coop Based } \\
\text { on Data from }\end{array}$} & & \\
\hline & Regency & Province & Regency & Province & & \\
\hline 2012 & 135,286 & & 53,578 & & 32 & \\
\hline 2013 & 138,755 & & 59,296 & & 32 & \\
\hline 2014 & 142,550 & & 60,834 & & 34 & \\
\hline 2015 (ID is introduced) & 135,595 & 150,223 & 53,191 & 61,912 & 36 & \\
\hline 2016 (closure was started) & n.a. & 151,170 & n.a. & 57,025 & 37 & \\
\hline 2017 & n.a. & 152,174 & n.a. & $24,247^{*}$ & 37 & \\
\hline 2018 & n.a. & 126,343 & n.a. & $21,417^{*}$ & 38 & 89 \\
\hline 2019 & n.a. & 123,048 & n.a. & $20,968^{*}$ & 40 & 85 \\
\hline growth 2012-15 & & & & $8 \%$ & $1.79 \%$ & \\
\hline growth 2012-19 & & & & $12 \%$ & $3.57 \%$ & \\
\hline
\end{tabular}

Source of data (4) and (5) are from https://www.transparency.org/en/cpi/2019, and https://www.transparency.org/en/ countries/indonesia\# 
The public discontent, especially inclinations among voters toward clientelist movements, also grows more significant due to the escalation of perceived corruption, especially when population earnings rise (Kitschelt \& Wilkinson, 2007a, 2007b; Singer 2009, Kitschelt, 2010, Hicken 2011). During the Suharto era, corruption eradication was done through formal civil society organizations (CSOs) (Setiyono \& McLeod, 2010). According to Transparency International (TI), from 2012 to 2015, the Indonesian corruption perception Index grew with an annual growth rate of $1.79 \%$ per annum, parallel with the annual growth of pseudo cooperatives that grew more rapidly 5.58\%. Later, when IGN Puspayoga, as the Minister of Cooperative from 20142019 , encouraged the development of good cooperatives, he tried to close down these pseudo cooperatives. Hence its growth decreased annually -12.12\% from 2012 to 2019. Unfortunately, fighting corruption is a tough job. From economic modeling using a game-theoretical approach, corruption tends to be stable (Kosfeld, 1997). Until the year of 2019, Indonesia's corruption perception Index was not decreasing but growing more rapidly at $3.57 \%$ per annum (as seen in Table 1 ).

Table 2. Descriptive Statistics of Indonesian Cooperatives of 2015

\begin{tabular}{|c|c|c|c|c|c|c|c|c|}
\hline \multirow{2}{*}{ Descriptions } & \multicolumn{7}{|c|}{ Islands } & \multirow{2}{*}{ Indonesia } \\
\hline & $\begin{array}{l}\text { Nusa } \\
\text { Tenggara }\end{array}$ & Java & Kalimantan & Maluku & Papua & Sulawesi & Sumatera & \\
\hline Total Cooperatives & 12,004 & 99,234 & 15,451 & 3,158 & 4,160 & 20,473 & 34,306 & 188,786 \\
\hline Active Cooperatives & 9,538 & 77,595 & 10,511 & 2,369 & 1,923 & 12,225 & 21,434 & 135,595 \\
\hline Pseudo-cooperatives & 2,466 & 21,639 & 4,940 & 789 & 2,237 & 8,248 & 12,612 & 52,931 \\
\hline $\begin{array}{l}\text { Pseudo Coops/Total } \\
\text { Coops }\end{array}$ & $20.5 \%$ & $21.8 \%$ & $32.0 \%$ & $25.0 \%$ & $53.8 \%$ & $40.3 \%$ & $36.8 \%$ & $28.0 \%$ \\
\hline Population (000) & $14,106.5$ & $144,799.2$ & $14,774.1$ & $1,685.2$ & $3,029.2$ & $16,965.1$ & $40,376.2$ & $235,735.4$ \\
\hline Annual Assembly & 5,419 & 35,852 & 2,779 & 494 & 537 & 2,944 & 6,858 & 54,883 \\
\hline Manager & 3,212 & 17,113 & 1,263 & 1,061 & 645 & 4,673 & 4,483 & 32,450 \\
\hline Coops/Population & $0.09 \%$ & $0.07 \%$ & $0.10 \%$ & $0.19 \%$ & $0.14 \%$ & $0.12 \%$ & $0.08 \%$ & $0.08 \%$ \\
\hline Internal Funding (IDR) & $3,779,993$ & $75,644,133$ & $5,213,066$ & 27,052 & 74,170 & $3,557,364$ & $18,036,800$ & $106,532,578$ \\
\hline External Funding (IDR) & $7,739,420$ & $64,065,773$ & $4,575,902$ & 1,764 & 70,201 & $2,130,835$ & $7,369,908$ & $86,133,803$ \\
\hline Surplus (IDR) & 495,379 & $11,703,592$ & 450,704 & 4,652 & 4,098 & 568,938 & $2,515,508$ & $15,852,871$ \\
\hline Average Volume (IDR) & $28,667.8$ & $242,003.2$ & $25,250.8$ & 11.3 & $2,195.2$ & $22,644.9$ & $55,449.8$ & $1,181.0$ \\
\hline
\end{tabular}

Notes: ${ }^{*}$ ) All IDR are in millions

Due to the slow process of data cleansing, the 2015 data at the regency level had a gap with provincial calculation even after removing the double-counting data. Hence, the only reliable data about pseudo cooperatives at the regency level was in 2015 (Table 2). The economic condition in 2015 is seen in Table 3. All of these data will be used and calibrated further in this paper in detail in cross section analysis, even though panel data exercise from 
2012-2014 is also applied separately. In 2019, the number of cooperatives' dissolution was still in progress, because there were 449 pseudo cooperatives erased from the data.

The average size of cooperative business in 2015 was IDR 1.181 million. Based on the SME law or Act No.20/2008 classification (bi.go.id, 2016), it fits the small business category. Only $72 \%$ of cooperatives are active, and about a total of 30.9 million cooperative members contribute 30 percent from the total labor force. The aggregate amount of external funding to Indonesia cooperatives was IDR 86,133,803 million, and the internal financing was IDR 106,532,578 million that gives the surplus of IDR 15,852,871 million. The cooperatives' Incremental Capital Output Ratio (ICOR) was 12.15, which is higher than 6.97, the ICOR of Indonesia in 2015 (Bank Mandiri, 2020). It reflects inefficiency in Indonesia's cooperatives. In quantitative research, the regional economic performance and dummy location is used as control variables in terms of all sectors in GRPD's data as seen in Table 3.

Table 3. The Economic conditions of Islands in exceptional year of 2015 (at Constant Price).

\begin{tabular}{|c|c|c|c|c|c|c|c|}
\hline & Sumatra & Java & $\begin{array}{l}\text { Bali \& Nusa } \\
\text { Tenggara }\end{array}$ & Kalimantan & Sulawesi & Maluku & Papua \\
\hline GRDP1 & $335,228,750$ & $401,773,530$ & $53,717,610$ & $86,346,070$ & $118,596,940$ & $5,992,890$ & $16,137,630$ \\
\hline GRDP 2 & $234,941,250$ & $117,341,000$ & $25,338,270$ & $268,748,240$ & $38,866,630$ & 810,290 & $13,845,830$ \\
\hline GRDP 3 & $320,148,490$ & $1,534,578,770$ & $13,380,120$ & $133,576,780$ & $57,582,530$ & $1,338,150$ & $19,064,890$ \\
\hline GRDP 4 & $2,411,060$ & $19,279,210$ & 356,930 & 436,750 & 375,050 & 24,850 & 51,060 \\
\hline GRDP5 & $1,148,380$ & $3,914,440$ & 401,720 & 832,750 & 655,550 & 120,920 & 110,660 \\
\hline GRDP6 & $146,058,860$ & $544,233,750$ & $26,033,600$ & $58,977,510$ & $61,305,960$ & $1,726,460$ & $12,320,060$ \\
\hline GRDP 7 & $164,679,690$ & $849,420,440$ & $28,539,040$ & $57,356,640$ & $62,015,080$ & $3,570,090$ & $11,229,510$ \\
\hline GRDP 8 & $57,418,660$ & $192,729,720$ & $17,950,020$ & $27,657,920$ & $22,193,940$ & $1,351,910$ & $4,925,930$ \\
\hline GRDP 9 & $17,472,540$ & $214,072,720$ & $26,856,980$ & $9,242,250$ & $6,233,190$ & 457,990 & 897,780 \\
\hline GRDP 10 & $41,526,150$ & $315,974,170$ & $15,335,130$ & $15,382,830$ & $24,583,970$ & 976,610 & $4,413,350$ \\
\hline GRDP 11 & $30,313,990$ & $252,580,980$ & $10,343,000$ & $16,723,370$ & $15,352,370$ & 921,200 & $2,346,810$ \\
\hline GRDP 12 & $31,843,890$ & $184,518,170$ & $10,161,000$ & $11,343,800$ & $15,468,010$ & 88,760 & $2,270,140$ \\
\hline GRDP 13 & $3,537,440$ & $128,460,400$ & $1,713,580$ & $2,048,660$ & $1,513,580$ & 261,790 & $1,115,960$ \\
\hline GRDP 14 & $52,435,930$ & $153,545,830$ & $19,523,610$ & $24,140,340$ & $27,429,260$ & $4,924,260$ & $12,030,310$ \\
\hline GRDP 15 & $29,924,060$ & $184,928,990$ & $15,602,530$ & $17,956,540$ & $23,003,470$ & $1,355,950$ & $2,888,650$ \\
\hline GRDP 16 & $13,014,660$ & $53,307,520$ & $5,823,480$ & $6,972,260$ & $10,191,720$ & 541,230 & $1,818,770$ \\
\hline GRDP 17 & $11,573,080$ & $114,035,970$ & $5,045,060$ & $5,135,770$ & $6,472,680$ & 426,560 & $1,037,460$ \\
\hline
\end{tabular}

Source: Calculated from data from Central Bureau of Statistics

In this case, when Java island is used as a benchmark, the pseudo entity's tendency is compared with other islands of Bali and Nusa Tenggara, Kalimantan, Sumatra, Sulawesi, and Papua. The four econometric models (one panel-data and three cross-section data) are as follow: 


$$
\begin{aligned}
& \text { PSEUDO }_{\text {it }}=\alpha_{0}+\alpha_{1} \text { EFUND }_{\text {it }}+\alpha_{2} \text { IFUND }_{\text {it }}+\alpha_{3} \text { BZVOL }_{\text {it }}+\alpha_{4} \mathrm{DV}_{\text {it }}+\alpha_{5} \mathrm{MAN}_{\mathrm{it}}+\alpha_{6} \mathrm{ANASS}_{\mathrm{it}}+ \\
& \alpha_{7} \mathrm{DCAP}_{\mathrm{it}}+\alpha_{8} \mathrm{SURPLUS}_{\mathrm{it}}+\alpha_{9} \mathrm{REGREV}_{\mathrm{it}}+\alpha_{10} \mathrm{ACTIVE}_{\mathrm{it}}+\alpha_{11} \mathrm{GRDP}_{\mathrm{it}}+\alpha_{12} \mathrm{CITYMAN}_{\mathrm{it}} \\
& +\alpha_{13} \text { SMALLMAN }_{\mathrm{it}}+\alpha_{14} \mathrm{POP}_{\mathrm{it}}+\varepsilon_{\mathrm{it}} \\
& +\alpha_{8} \text { SURPLUS }_{\mathrm{i}}+\alpha_{9} \text { REGREV }_{\mathrm{i}}+\alpha_{10} \text { ACTIVEC }_{\mathrm{i}}+\alpha_{11} \text { ISLAND }_{\mathrm{i}}+\alpha_{12} \mathrm{GRDP}_{\mathrm{i}}+\alpha_{13} \mathrm{CITY}_{\mathrm{i}}+ \\
& \alpha_{14} \text { CITYMANi }+\alpha_{15} \text { SMALLMANi }+\alpha_{16} \text { POP }_{\mathrm{i}}+\varepsilon_{\mathrm{I}}
\end{aligned}
$$

$\mathrm{PC}_{\mathrm{i}}=$ Pseudo-cooperatives as dependent variable at regencies and cities; $i=$ Regencies or Cities; $\alpha_{0}=$ Intercept. The double log is applied both in independent and dependent variables. Hence all the parameters reflect elasticities. However, the exception is given for the dummy variable and the gearing ratio. In this case $\alpha_{0}$ is the intercept. Some variables are included in this exercise even though it is expected to be insignificant because this is the regional aggregate data that mix the inactive or pseudo-cooperatives with active cooperatives. The dependent variables are EFUND ${ }_{\mathrm{i}}$ or the External Funding. Due to perverse incentives, the elasticity $\alpha_{1}$ will be positive; it means the more External Funding the more the number of pseudo-cooperatives. IFUND ${ }_{\mathrm{i}}$ is the Internal Funding and $\alpha_{2}$ is its elasticity with positive hypothesis because it will create burden to cooperatives and create more seudo-cooperatives.

$\mathrm{BZVOL}_{\mathrm{i}}$ is the Business Volume that explains the amount of annual asset of cooperatives and $\alpha_{3}$ is its elasticity with negative hypothesis because the bigger volume of cooperative will be more efficient and more sustainable to cooperatives that in turn will reduce the number of pseudo-cooperatives. But this is the common facts for healthy cooperatives. In pseudo-cooperatives it might be positive, because people with moral hazard usually fonder of the big money, not the small one. It is seen in the too big to fail' phenomena in banking (Mattana et al., 2015). In this case $\mathrm{DV}_{\mathrm{i}}$ is the Dummy Business; it is created based on Law 20/ 2008 about Micro, Small and Medium Enterprise classification and Volume < IDR 300 million is considered as micro enterprises and $\alpha_{4}$ $=$ is the elasticity. The hypothesis is also negative because the micro volume of business will be easier to manage and less prone to moral hazard to become pseudo-cooperatives. MAN $_{\mathrm{i}}$ is the number of Manager and $\alpha_{5}$ is its elasticity which is expected to be positive because according to discussions with some cooperative's player, to have a manager is burdensome in cooperative, and there is an idea to have a manager to manage several cooperatives albeit its potential conflict of interest; hence $\alpha_{5}$ will increase the number of pseudo-cooperatives. ANASS is the Annual Assembly with $\alpha_{6}$ as the elasticity of this variable. It is expected to be insignificant because pseudo-cooperatives never do the annual assembly. 
DCAP $_{\mathrm{i}}$ is the Dummy Capital, it is made based on Law 20, 2008 about Small Medium Enterprise and the parameter $\alpha_{7}$ will be divided into $\alpha_{7 \mathrm{a}}$ for the dummy of small enterprise with capital size with the range of IDR 50 million < capital $\leq$ IDR 500 million and $\alpha_{7 \mathrm{~b}}$ is for the dummy of medium enterprise with IDR 500 million < capital $\leq$ IDR 10 billions. The benchmark is the big cooperative with capital more than IDR 10 billions. $S_{i}$ is the Surplus or the cooperative's annual yield that some of it will be divided to cooperatives' members.

Its elasticity $\alpha_{8}$ is expected to be insignificant due to the fact that pseudo-cooperatives are inactive so there will be no surplus. Why surplus is included in this exercise, because this is the regional aggregate data in regency or city, so the number appears in Surplus is mixed with those of active cooperatives. REGREV $\mathrm{R}_{\mathrm{i}}$ is Regional Revenue with its elasticity $\alpha_{9}$ is expected to be significantly positive due to the fact that pseudo-cooperatives possess 'subsidy mentality' and will rely on regional government subsidy; ACTIVE $_{\mathrm{i}}$ is Active Cooperatives with its elasticity $\alpha_{10}$ is expected to be insignificant because pseudo-cooperatives will not be inspired by active cooperatives.

ISLAND $_{\mathrm{i}}$ is the Dummy Island as control variable with Java island as benchmark with its elasticity $\alpha_{11}$ is divided into six other islands, $\alpha_{11 \mathrm{a}}$ for Sumatra, $\alpha_{11 \mathrm{~b}}$ for Kalimantan, $\alpha_{11 \mathrm{c}}$ for Sulawesi, $\alpha_{11 \mathrm{~d}}$ for Bali and Nusatenggara, $\alpha_{11 \mathrm{e}}$ for Maluku, and $\alpha_{11 \mathrm{f}}$ for Papua. GRDP is the value added as expressed from seventeen sectors in GRDP (Gross Regional Domestic Product) at the regency or city level that become the control variables. It is expected that some of the elasticities $\alpha_{12}$ of this variables are significant especially those related with the government service sectors since pseudo-cooperatives with 'subsidy mentality' mostly rely on the government's support. CITY is the Dummy City and its parameter $\alpha_{13}$ is expected to be positive because people who live in the city will be less punitive to crime (The Conversation, 2019) and will tend to create more pseudo-cooperative compare to the rural location; CITYMAN $_{i}$ is the interaction of the Dummy City and the number of Manager and its elasticity $\alpha_{14}$ will be positive because Cooperative Managers who live in the city will tend to create more pseudo-cooperative compare to the rural location.

SMALLMAN $_{i}$ is the interaction of the Dummy Small size of capital mentioned above and the number of Manager and its elasticity $\alpha_{15}$ is expected to be positive because manager in small cooperatives tend to create more burden that induced inactive cooperatives. POP ${ }_{i}$ is the population of the regencies and its elasticity $\alpha_{16}$ is expected to be positive because the 'subsidy mentality' in cooperatives starts from the top level of Indonesian cooperatives and this influence nationwide, hence the bigger the population, the bigger the number of pseudocooperatives. In equation three, the difference from equation two is located at the gearing ratio or GEAR that shows calculated risk as a percentage of external funds as the numerator from the denominator as total amount of institutional and member capital plus the external funds. The higher the gearing ratio, the higher the risk the cooperative runs in losing their assets in the event of inability to repay a loan (FAO.org2). When gearing ratio is included,

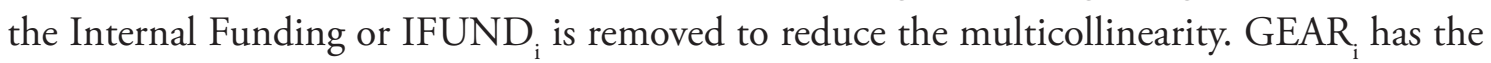
elasticity $\beta$ that expected to be negative for pseudo-cooperatives with moral hazard because they don't concern about calculated risk at all. When the percentage of external funding compare to its denominator consists of external and internal funding, this amount will be 
smaller when external funding increases. Equation two also removes the REGREV $\mathrm{i}_{\mathrm{i}}$ or the Regional Revenue to find its effect.

In Equation four, all dummy islands as control variables are removed from equation two to see the influence at the national level. In this research, the quantitative analysis uses robust regression instead of the OLS because of its insensitivity to outliers and possibly high leverage points, use Indonesia's 463 regencies and cities' cross-section data from 188,786 cooperatives in 2015. Jarque-Bera test is performed based on the normality test. Robust regression with performing the iterative solution able to erase abnormal error distribution. Hence, the estimating equations are solved. It is equivalent to a weighted least-squares problem. The weights depend upon the residuals, while the residuals depend upon the estimated coefficients, and the estimated factors depend upon the weight (Fox et al., 2013). Due to the heterogeneity of cross-sections, it is common that the R-squared is not too high, acceptable even if only 0.156 .

According to Oster (2019), the quality of the control variable is diagnosed by how the $R$-squared moves and coefficient stability when the controls are introduced. The summary of one panel-data 2012-2014 using fixed effect and three robust regressions from crosssection data in 2015 can be seen in Table 4, using the same dependent variable of pseudocooperatives influenced by many independent variables mentioned above. The exercise uses a double log to directly know the elasticity of the variable toward the existence of pseudocooperative at the regency level. The cross-section and time-series data being used in 20122015 belong to the Ministry of Cooperatives. It is in the form of 188,786 cooperatives' data at 463 regencies or city level at the year of 2015. The Ministry collected the data in preparation to solve the pseudo-cooperative problem. This research also uses macroeconomic data about regional revenues and Gross Domestic Regional Product (GRDP) from the Central Bureau of Statistics.

\section{Results and Discussions}

Cooperative is just a variety of company forms, only one type among many kinds of enterprise. Cooperative has an important role to play in developing the institutional variety in the market economy (Normark, 1996). However, as a non-profit organization, cooperatives are different from a limited company (the production of a profit for its owners), while cooperative is for its members (Skurnik, 2002). The surplus is returned to the members in proportion to their use of the company's services, after making the reserves necessary to develop the company. If there is external financing penetrates to cooperatives, it will go through cooperative's business operations, to the overlapping area of business operations in these enterprises. Capital can come from three primary sources (FAO.org1): directly from members, from retained surpluses generated by the cooperative business, and from outsiders.

Cooperative can play significant role in the new social economy (Czternasty, 2014). Cooperatives can be an effective participatory strategy to bootstrap low-income people into the socio-economic mainstream (Majee \& Hoyt, 2011; Mhembwe \& Dube, 2017). Azhari 
et al. (2017) show that cooperative has contributed less than $2 \%$ of the Indonesia's gross domestic product and offered $0.5 \%$ job vacancy.

The gearing ratio (FAO.org2) shows the calculated risk. The previous cooperatives' cross-section econometric exercise about the difference between members' expectations and perceptions using primary data was done by Richard et al. (1998) in Alberta, USA. They show how principle agent problems took place that discovered from various socioeconomic variables that influence the coverage to which the cooperatives' objectives are not always fulfilled. However, the previous regional aspect of cooperatives' research was found in South Africa in 2014, using 266 primary data randomly selected active and inactive cooperatives. Logistic regression was used. The study results indicated that support for cooperatives across the nine provinces of South Africa was deficient from the provincial and municipal development agencies (Nkonki-Mandleni \& Anim, 2014). Similar to Alberta's case, the South African study used questionnaires to collect data from 266 cooperatives.

As explained previously, that pseudo cooperative's data before 2015 (from 2012-2014) was in a mess due to double counting. However, this chaotic data used as a panel data exercise was tested to find which model is the best. Based on Chow test, the Fixed Effect is the best model based on Prob $>F=0.0000$ : and P-Value $($ Prob $>F)<$ Alpha 0,05. From the Hausman test, the Fixed Effect model is also better and not the Random Effect due to Prob $>$ chi2 = 0.0000. Hence the fixed Effect model is applied in model 1, as seen in Table 4. The only significant independent variable is the active cooperative data with elasticity 0.47 . It means that if active cooperatives increase one hundred units, the number of pseudo cooperative decrease 47 unit. The other significant variables are GRDP sector 4 (Electricity and Gas) and GRDP 17 (Other Services Activities).

There are three models for the 2015 cross-section data exercise (models 2, 3, and 4). It seems that the external funding in the Indonesian cooperative influences the increasing number of pseudo-cooperatives, reflecting the perverse incentive and subsidy mentality (in 2 and 4). In these models, the magnitude of internal funding also influences positively in increasing the pseudo-cooperative with a more significant amount (more elastic) compare to the external funding. It means that the decision to create inactivity in cooperatives is influenced more by the cooperative itself.

The gearing ratio (the external funding divided by the internal plus external financing) will be less than one, as seen in model 3. The external funding itself, if combined with gearing ratio, is not significant. However, because the gearing ratio already contains the element of external financing, it also reflects the same phenomena of external funding influence. The negative sign of gearing ratio means the magnitude of internal funding as the denominator plus the external funding is higher compare to external funding itself as the numerator.

From all three models from cross-section 2015 (models 2, 3, and 4), it seems that the small and medium-capital of the coop (DCAP) with annual selling less (BZVOL) than Rp 300 million is effective in reducing the pseudo-cooperatives' existence. This research can reveal that the 'too big to fail' phenomenon doesn't exist in small cooperatives since the 
crooks are only interested in big money, not the small one. Hence the 'small is beautiful' wonders, as Schumacher (1973) said, can save the spirit of cooperatives in Indonesia.

It is also found that the bigger the population, the more the number of pseudocooperatives. As the top-level of a cooperative body, Dekopin's influence problem induces moral hazard all over the country. However, the city location and regional revenue are not significant; it means there is no difference in the city or rural area in creating pseudocooperative. There is no influence of local revenue as well. The other insignificant variables are surplus, the number of managers, and the annual assembly.

Based on the cross-section exercise in models 2, 3, and 4, the GRDP Sector 8 (Transportation and Storage) induce the increasing number of pseudo-cooperatives because this sector records the mobility that creates a more significant burden for these organizations to develop. After all, the proximity and locality of the cooperative activity must be inducing its growth based on the 'think globally act locally' approach (Dunlap, 2018; Watanabe, 2018). On the other hand, the GRDP Sector 10 (Information and Communication) and GRDP Sector 14 (Public Administration and Defense; Compulsory Social Security) influence the opposite direction.

Table 4. Panel data 2012-2014 and Cross-section model of 2015

\begin{tabular}{|c|c|c|c|c|}
\hline $\begin{array}{c}\text { Dependent variable LN Pseudo } \\
\text { Coops }\end{array}$ & $\begin{array}{c}\text { Panel Data of regency } \\
\text { data from } 2012-2014 \\
\text { with Fixed Effect as the } \\
\text { best model }\end{array}$ & [95\% Conf. Inter] & al] from 2015 Cros & Section Data \\
\hline \multirow{2}{*}{ Model } & Model 1 & $\begin{array}{l}\text { Model } 2 \text { ( Java as } \\
\text { benchmark) }\end{array}$ & $\begin{array}{l}\text { Model } 3 \text { (Java as } \\
\text { benchmark) }\end{array}$ & $\begin{array}{l}\text { Model } 4 \text { (No } \\
\text { benchmark) }\end{array}$ \\
\hline & Coef. (t) & Coef. (t) & Coef. (t) & Coef. (t) \\
\hline LN Number of Active Cooperative & $-0.47^{* * *}(-8.28)$ & $0.017(0.18)$ & $0.026(0.27)$ & $-0.026(-0.280$ \\
\hline LN Regional Revenue (IDR) & $-0.038(-1.10)$ & $0.074(1.12)$ & - & - \\
\hline LN External Capital (Million IDR) & $-.00017(-0.01)$ & $0.089^{* *}(2.01)$ & $0.142(1.51)$ & $0.159^{*}(1.74)$ \\
\hline $\begin{array}{l}\text { LN (Regional Revenue* External } \\
\text { Funding) }\end{array}$ & - & - & $0.063(0.97)$ & $-.031(-0.49)$ \\
\hline LN Internal Capital (in million IDR) & $0.003(0.14)$ & $0.134^{* * *}(2.65)$ & - & - \\
\hline Gearing Ratio (\%) & - & - & $-0.689 * *(-2.43)$ & $-0.370(-1.29)$ \\
\hline LN Business Volume (Million IDR) & $0.009(0.44)$ & $-0.021(-0.38)$ & $-0.017(-0.30)$ & $-0.013(-0.24)$ \\
\hline LN Surplus (Million IDR) & $0.015(0.91)$ & $-0.028(-0.66)$ & $-0.026(-0.58)$ & $0.005(0.11)$ \\
\hline LN of the Annual Assembly & $0.018(0.84)$ & $0.071(1.19)$ & $0.073(1.23)$ & $-0.004(-0.06)$ \\
\hline LN of the number of managers & $-0.017(-0.55)$ & $0.066(0.92)$ & $0.075(1.03)$ & $0.042(0.58)$ \\
\hline Dummy of the City & Omitted & $0.196(0.67)$ & $0.213(0.73)$ & $0.309(1.13)$ \\
\hline $\begin{array}{l}\text { Dummy of Volume Micro Annual } \\
\text { Asset (<IDR } 300 \text { million = 1) }\end{array}$ & $-0.014(-0.42)$ & $-0.187^{* * *}(-3.04)$ & $-0.195^{* * *}(-3.16)$ & $\begin{array}{l}-0.183^{* * *}(- \\
2.96)\end{array}$ \\
\hline Dummy City* Number of Manager & $-0.066(-1.20)$ & $-0.011(-0.13)$ & $-0.011(-0.13)$ & $-0.045(-0.62)$ \\
\hline $\begin{array}{l}\text { Dummy of Micro Capital size ( } 50 \\
\text { million }<\text { IDR }<=500 \text { million) }\end{array}$ & $-0.049(-0.42)$ & $-0.584^{* *}(-2.32)$ & $-0.571^{* *}(-2.24)$ & $\begin{array}{l}-0.717^{* * *}(- \\
2.77)\end{array}$ \\
\hline $\begin{array}{l}\text { Dummy Small capital coop in IDR ( } \\
500 \text { million < Capital <=10 billion) }\end{array}$ & $-0.074(-0.85)$ & $-0.795^{* * *}(-3.53)$ & $\begin{array}{c}-0.780^{* * *}( \\
-3.40)\end{array}$ & $\begin{array}{l}-0.748^{* * *}(- \\
3.33)\end{array}$ \\
\hline $\begin{array}{l}\text { Dummy of Volume Small Asset ( } \\
\text { 300million < IDR <=2,5 billion) }\end{array}$ & $-0.035(-0.29)$ & $0.271(1.32)$ & $0.305(1.47)$ & $0.274(1.30)$ \\
\hline
\end{tabular}


Signifikan: Jurnal IImu Ekonomi

Volume 9 (2), 2020: 219 - 240

\begin{tabular}{|c|c|c|c|c|}
\hline $\begin{array}{c}\text { Dependent variable LN Pseudo } \\
\text { Coops }\end{array}$ & $\begin{array}{l}\text { Panel Data of regency } \\
\text { data from } 2012-2014 \\
\text { with Fixed Effect as the } \\
\text { best model }\end{array}$ & [95\% Conf. Inte & al] from 2015 Cros & Section Data \\
\hline \multirow[t]{2}{*}{ Model } & Model 1 & $\begin{array}{l}\text { Model 2( Java as } \\
\text { benchmark) }\end{array}$ & $\begin{array}{l}\text { Model } 3 \text { (Java as } \\
\text { benchmark) }\end{array}$ & $\begin{array}{l}\text { Model } 4 \text { (No } \\
\text { benchmark) }\end{array}$ \\
\hline & Coef. $(t)$ & Coef. $(t)$ & Coef. (t) & Coef. $(t)$ \\
\hline $\begin{array}{l}\text { Dummy Volume Medium Asset in ( } \\
2,5 \text { Billion }<\text { IDR }<=50 \text { Billion) }\end{array}$ & $-0.147(-1.02)$ & $0.114(0.36)$ & $0.172(0.54)$ & $0.154(0.48)$ \\
\hline Dummy_Small Capital * Manager & $0.011(0.35)$ & $0.025(0.36)$ & $0.019(0.29)$ & $0.071(1.05)$ \\
\hline $\begin{array}{l}\text { GRDP1 Agriculture, Forestry and } \\
\text { Fishing }\end{array}$ & $-0.255(-0.71)$ & $0.062(0.86)$ & $0.061(0.84)$ & $0.182^{* *}(2.44)$ \\
\hline GRDP 2 Mining and Quarrying & $-0.036(-0.35)$ & $0.024(1.03)$ & $0.025(1.09)$ & $0.005(0.26)$ \\
\hline GRDP 3 Manufacturing & $0.049(0.16)$ & $0.013(0.32)$ & $0.009(0.25)$ & $0.043(1.06)$ \\
\hline GRDP 4 Electricity and Gas & $0.481^{* *}(2.35)$ & $0.075(1.51)$ & $0.074(1.49)$ & $0.079(1.48)$ \\
\hline $\begin{array}{l}\text { GRDP5 Water supply, Sewerage, } \\
\text { Waste Management and } \\
\text { Remediation Activities }\end{array}$ & $0.452(1.28)$ & $0.051(1.24)$ & $0.051(1.25)$ & $0.102^{* *}(2.29)$ \\
\hline GRDP6 Construction & $-0.098(-0.53)$ & $0.152(1.38)$ & $0.156(1.41)$ & $0.206^{*}(1.82)$ \\
\hline $\begin{array}{l}\text { GRDP } 7 \text { Wholesale and Retail } \\
\text { Trade; Repair of Motor Vehicles } \\
\text { and Motorcycles }\end{array}$ & $0.906(1.52)$ & $0.024(0.19)$ & $0.013(0.10)$ & $0.163(1.28)$ \\
\hline $\begin{array}{l}\text { GRDP } 8 \text { Transportation and } \\
\text { Storage }\end{array}$ & $-0.093(-0.37)$ & $0.102^{* *}(1.97)$ & $0.098^{*}(1.88)$ & $0.107^{* *}(2.02)$ \\
\hline $\begin{array}{l}\text { GRDP } 9 \text { Accommodation and } \\
\text { Food Service Activities }\end{array}$ & $-0.061(-0.14)$ & $0.063(1.10)$ & $0.067(1.16)$ & $-0.003(-0.05)$ \\
\hline $\begin{array}{l}\text { GRDP } 10 \text { Information and } \\
\text { Communication }\end{array}$ & $-0.011(-0.03)$ & $-0.168^{* *}(-2.19)$ & $-0.170^{*}(-2.20)$ & $\begin{array}{l}-0.224^{* * *}(- \\
2.98)\end{array}$ \\
\hline $\begin{array}{l}\text { GRDP } 11 \text { Financial and Insurance } \\
\text { Activities }\end{array}$ & $0.100(0.37)$ & $-0.064(-0.69)$ & $-0.062(-0.67)$ & $-0.001(-0.01)$ \\
\hline GRDP 12 Real Estate Activities & $-0.101(-0.17)$ & $-0.004(-0.06)$ & $0.001(0.02)$ & $\begin{array}{l}-0.133^{* *}(- \\
2.36)\end{array}$ \\
\hline GRDP 13 Business Activities & $0.176(0.54)$ & $-0.006(-0.17)$ & $-0.007(-0.21)$ & $0.0178(0.54)$ \\
\hline $\begin{array}{l}\text { GRDP } 14 \text {-Public Administration } \\
\text { and Defence; Compulsory Social } \\
\text { Security }\end{array}$ & $0.435(1.10)$ & $-0.261^{* *}(-2.38)$ & $-0.278^{* *}(-2.56)$ & $-0.018(-0.18)$ \\
\hline GRDP 15 -Education & $0.304(0.73)$ & $-0.094(-0.93)$ & $-0.097(-0.98)$ & $-0.138(-1.27)$ \\
\hline $\begin{array}{l}\text { GRDP } 16 \text { Human Health and } \\
\text { Social Work Activities }\end{array}$ & $0.226(0.47)$ & $0.173^{*}(1.73)$ & $0.1740 *(1.72)$ & $0.28^{* * *}(3.03)$ \\
\hline GRDP 17 Other Services Activities & $-1.349(-2.65)$ & $-0.0181(-0.31)$ & $-0.008(-0.15)$ & $-0.076(-1.25)$ \\
\hline LN Population & $1.004(1.380$ & $0.425^{* * *}(2.68)$ & $0.454^{* * *}(2.89)$ & $0.186(1.13)$ \\
\hline Dummy of Sumatra Island & Omitted & $0.467^{* * *}(2.58)$ & $0.499^{* * *}(2.76)$ & - \\
\hline $\begin{array}{l}\text { Dummy of Bali NusaTenggara } \\
\text { Islands }\end{array}$ & Omitted & $-0.23(-1.09)$ & $-0.210(-1.00)$ & - \\
\hline Dummy of Kalimantan Island & Omitted & $0.256(1.26)$ & $0.284(1.39)$ & - \\
\hline Dummy of Sulawesi Island & Omitted & $0.611^{* * *}(2.71)$ & $0.633^{* * *}(2.81)$ & - \\
\hline Dummy of Maluku Island & Omitted & $0.988^{* * *}(3.15)$ & $1.008^{* * *}(3.24)$ & - \\
\hline Dummy of Papua Island & Omitted & $1.443^{* * *}(4.84)$ & $1.501^{* * *}(5.07)$ & - \\
\hline Constanta & $-17.869(-2.00)$ & $-5.118^{* * *}(-3.97)$ & $-4.778^{* * *}(-3.67)$ & $-5.44^{* * *}(-4.16)$ \\
\hline Number of observations & $\begin{array}{l}1,210 \text { with number of } \\
\text { groups }=435\end{array}$ & 400 & 400 & 400 \\
\hline
\end{tabular}




\begin{tabular}{|c|c|c|c|c|}
\hline $\begin{array}{c}\text { Dependent variable LN Pseudo } \\
\text { Coops }\end{array}$ & $\begin{array}{c}\text { Panel Data of regency } \\
\text { data from } 2012-2014 \\
\text { with Fixed Effect as the } \\
\text { best model }\end{array}$ & [95\% Conf. Inte & al] from 2015 Cros & Section Data \\
\hline \multirow[t]{2}{*}{ Model } & Model 1 & $\begin{array}{l}\text { Model } 2 \text { ( Java as } \\
\text { benchmark) }\end{array}$ & $\begin{array}{l}\text { Model } 3 \text { (Java as } \\
\text { benchmark) }\end{array}$ & $\begin{array}{l}\text { Model } 4 \text { (No } \\
\text { benchmark) }\end{array}$ \\
\hline & Coef. (t) & Coef. (t) & Coef. (t) & Coef. (t) \\
\hline $\begin{array}{l}F(33,742) \text { model } 1 \text { and } F(40, \\
359) \text { model } 2,3,4\end{array}$ & 43.81 & 15.12 & 15.2 & 14.22 \\
\hline Prob $>\mathrm{F}$ & 0 & 0 & 0 & 0 \\
\hline R Squared & & 0.5807 & 0.5795 & 0.5335 \\
\hline R Squared within & 0.1818 & & & \\
\hline R Squared between & 0.2729 & & & \\
\hline R Squared overall & 0.2645 & & & \\
\hline Root MSE & 0.71643 & 0.72475 & 0.72572 & 0.75807 \\
\hline
\end{tabular}

The difference is found in model 3 when the dummy islands are removed. The significance in GRDP Sector 16 (Human Health and Social Work Activities) in model 1 and 2 disappears. It is replaced by GRDP Sector 1 (Agriculture, Forestry and Fishing), GRDP Sector 5 (Water Supply, Sewerage, Waste Management, and Remediation Activities) and GRDP Sector 12 (Real Estate Activities). It means that these sectors are not robust. On the other hand, the increasing value-added of the information and communication sector (GRDP 10) are very sturdy in all three models to reduce pseudo-cooperatives. In contrast, public administration, defense, and compulsory social security sectors (GRDP 14) are significant in models one and two and can reduce pseudo-cooperatives.

By using Java island as a dummy island benchmark, a smaller tendency of the pseudo entity is found in Sumatra's islands, Sulawesi, as seen from their significant but with the magnitude of parameter less than one. However, this magnitude of the parameter is not consistent in Maluku (in model one, it is smaller than one, but in model two, it is bigger than one). In Papua, a more significant tendency of the pseudo entity is found compare to Java. In contrast with the similar benchmark, Bali, Nusa Tenggara, and Kalimantan islands are not significant in influencing the increase of pseudo-cooperatives in these areas.

As expected, the R-squared in this research is around 0.53 to 0.58 ; it is not too high, but acceptable. According to Oster (2019), the quality of the control variable is diagnosed by how $R$-squared moves and coefficient stability when the controls are introduced. In model three, the control variable of dummy islands when removed from equations one and two does not change the R-squared significantly, only from 0.58 to 0.53 . In many cross-country or cross-regional analyses, Oster looks for to control for geographic differences across areas. Since the GRDPs already represent the control variable, hence, the dummies of islands' removal do not influence that much movement.

The expected agent for change for cooperatives actor, as the spirit of 'think globally act locally' is severely challenged by the fact that the GRDP Sector 8 (Transportation and Storage) induce the increasing number of pseudo-cooperatives. This sector's significance 
reflects that the cooperatives' players often use external funding as a means to spend them through traveling for leisure and not use them to create a sustainable cooperative's business. Fortunately, albeit its tiny steps, but due to the 'Small is beautiful' spirit, it is shown that cooperatives with micro size, with the volume of the annual asset below IDR300 million, are found healthier. If this type of cooperatives is developed and practiced by people all over the country, it will create more value-added and sustainability and able to fill the real meaning to the Indonesian independence based on a self-help attitude.

The strategy to cope with pseudo cooperatives is connected with the increasing perceived corruption in Indonesia. According to an interview, the leader of rural electrification has regretted Dekopin's head position because this strategic position is filled by a former prisoner who wants to retain his seat for a lifetime. The Sahara cooperative leader said that the Dekopin's election is not democratic; that is why the cooperative movement is not sound in Indonesia. According to the Secretary-General of the Indonesian Credit Union Association, the regional governments also have some moral hazard in pouring the funding to organizations since some of them want to receive the kickback from the disbursed money. A Cooperative expert from the Ministry of Cooperative and SMEs said that based on his survey, the role of Dekopin is deceitful since they receive the government funding.

Due to increasing public rage due to remembering Nurdin Halid's past as an exconvict and his desire to continue leading Dekopin, a self-help effort emerged to expel him from his top position. A petition tried to cancel the disbursement of the state budget to this institution. If government funds stop pouring into Dekopin, surely Nurdin will leave his chairman position (change.org. 2016). The petition was uploaded through change.org, to rescind the Dekopin's status as a parastatal (a Non-Structural Institution) and annul its privilege to receive approximately IDR 50-80 billion state-budget funds annually (change.org. 2016). Unfortunately, the petition failed. The organization culture in Dekopin is maintained by force or 'perspiration,' not by 'aspiration' (Soesilo, 2016). From economic modeling using the game-theoretical approach, corruption tends to be stable, depending on the prospective behavior of the society given by the payoff function of the basic Prisoner's Dilemma game and the cost function of the establishment. (Kosfeld, 1997). In a nutshell, the political spectrum of cooperatives is still more dominant in Indonesia than the economic side, because a heroic movement from any level (bottom-up or top-down approach) of the country to remove the state budget for Dekopin is never fruitful.

The position of Dekopin is stable because the political side of cooperatives' policy is more durable than the economic front. Historically it was aimed to protect the ruling party's majority vote that influences the increasing number of pseudo cooperatives. It can't be changed due to the 'holdup problem' with 'stable corruption' (Kosfel, 1997). Based on Situmorang's study in North Sumatra, East Java, Bali and West Kalimantan provinces, with respondents of this study consisted of the managers of Dekopin, management of cooperatives, and the State Civil Apparatus, in general, it can be concluded that Dekopin plays a less role in the development of Indonesian cooperatives (Situmorang, 2017). The spectrum of Dekopin's 
disreputable leadership that gives an adverse influence problem to the grassroots level that ruins the cooperative's ideal role as vibrating machines for national and local development. Hence, an effort to create healthy cooperatives within its jurisdiction was severely needed. IGN Puspayoga, the Indonesia’s Minister of Cooperatives and SME 2014-2019, started this effort in 2015.

As part of a strategy to cope with pseudo cooperatives is by creating the compulsory Cooperative Identification Number. It was started in 2015 by Minister IGN Puspayoga, and 2015 was an exceptional year because this rule was applied with coercion, albeit it creates the gap in 2015 data between provincial and regency data (as seen in graph 1). If cooperatives had no annual assembly activity, their formal existence would be erased. Hence the total number of cooperatives in 2015 was lesser compare to the previous years. After cleansing the data in 2015, as seen in table 2, the closure of cooperatives was started in 2016.

IGN Puspayoga, as the Minister of Cooperative and Small Medium Enterprise, began to dissolve some inactive or pseudo cooperatives in Indonesia. On December 22, 2016, he launched a decision letter 114/KEP/M.KUKM.2/XII/2016 to close down 32,778 cooperatives. Another decision letter in 2017 was Kemenkop UKM No. 65 / KEP / M.KUKM.2.VII / 2017. In 2018, he released another Decree of the Ministry of Cooperatives and SME number 154 of 2018 about the first amendment to the previous year's decision concerning the dissolution of cooperatives. According to the Government Regulation number 17 in 1994, even though the Minister of cooperatives has the legal authority to dissolve the organizations, but the cooperative members are allowed to express their objection of the demise within two months (in practice this process is six months). Hence the cooperative data from 2016 to 2019 were in a mess. In 2019, during Minister Teten Masduki's term (2019-2024), who replaced IGN Puspayoga (2014-2019), 81,686 pseudo cooperatives were dissolved in Indonesia. In the last four years, consecutively in 2016, 2017, 2018, and 2019, the number of cooperative dissolutions was 45,629; 32,778; 2,830 and 449 as mentioned by the new Secretary of the Ministry of Cooperatives and SMEs Rully Indrawan in his official statement.

\section{Conclusion}

This study incorporates several revelations to shed light on such an issue of pseudocooperatives as a contextual reason behind the government's decision to close down some of them. However, the political spectrum of cooperatives is still more dominant in Indonesia than the economic side of regulation. Dekopin, the apex cooperative organization, has a 'stable corruption' image because of Nurdin Halid with his money politics. He is a former corruption inmate who can stay as a 'perpetual' leader for at least four consecutive terms incessantly even when he stayed in prison. Dekopin is a 'bureaucratic capitalist' since it became a parastatal with state budget support that forces the 'holdup problem,' or a contractual relationship influenced by a specific assets scheme pursues to exploit the other faction's weakness. Albeit public outcry, a bottom-up movement through petition to remove the state budget to Dekopin was not fruitful. Hence, it creates a perception that corruption is inevitable, and 'clientelism' is the easiest way to gain power. Cooperative's 
initiation is perceived as a top-down approach from the bureaucracy and not from the people itself. No wonder that conflict is never ceased. The 'hyphenated society' during Soekarno Hatta happened in Dekopin as well. As the organization culture can't be changed while the number of pseudo cooperatives increased, an arduous effort to create healthy cooperatives is severely needed. Within the Ministry's jurisdiction, the closing down of pseudo cooperatives is just the beginning. More bravery from the government is required to return the proper cooperative's status as an efficient socio-economic agent with equal force compared to the government's side by removing state budget support to Dekopin, to spur the cooperatives' self-help initiation.

After pseudo-cooperative dissolution, Indonesia needs good collaborative governance and a standard metric to induce better motivation. The combined advice from CGAP (2005) and Shankar (2002) and the research findings are relevant to building cooperatives. First, to take advantage of the information and communication sector \& public administration, defense, and compulsory social security sectors to reduce further of the perverse incentive in cooperatives through tailor-made information and technology to reduce the subsidy mentality of people nationwide. Second, create a proactive approach in learning new ways of adapting to change and re-engineering themselves. It is done by backing the competent one, such as the micro but healthy cooperatives with small-medium-capital that can be used as a model in building the right image of the organizations and highlighting the basic new set of skills to win in the competitive market. Third, cancel the existence of State Budget to Dekopin and primary cooperative to abolish subsidy mentality, create more sound good governance, and create weaning scenarios with tailor-made preferential treatment benefits. Fourth, supporting the cooperative entity that wants to learn new techniques from best practices found in many islands. Fifth, intensifying the independent external supervision and empowerment, especially in Eastern Islands (in Maluku and Papua), reduces the tendency to use the funding for unnecessary travel and concentrates resources on cooperatives that are willing to implement sound policies and standards.

\section{References}

Abdurrahman, M. N. (2019). Nurdin Halid Keempat Kalinya Terpilih Jadi Ketua Dekopin (Nurdin Halid won for the fourth time as Dekopin's Chairman). Retrieved April 10, 2020, from detikFinance: https://finance.detik.com/berita-ekonomi-bisnis/d-4783942/ nurdin-halid-keempat-kalinya-terpilih-jadi-ketua-dekopin

Anwar, R. (2002). In Memoriam: Mengenang Yang Wafat (in Memoriam: Remembering the Dead). Jakarta: Penerbit Buku Kompas.

Azwari., Syechalad, M. N., Hasan, I., \& Majid, M. S. A. (2017). The Role of Cooperative in the Indonesian Economy. International Journal of Humanities and Social Science Invention, 6(1), 43-46.

Bank Mandiri. (2020). Indonesia's Economic Outlook 2020. Jakarta: Bank Mandiri.

bin-Joharie, A. R. (1988). An Analysis of Agriculture Subsidies in the Rubber and Padi Sector of Malaysia. (Unpublished Dissertation). University of Bath. 
Bobbio, N. (1997). Left and Right: The Significance of a Political Distinction. Chicago: University of Chicago Press.

CGAP . (2005, August). Working with Savings \& Credit Cooperatives. (Donor Brief No. 25) Retrieved February 20, 2020, from www.cgap.org: https://www.cgap.org/sites/ default/files/CGAP-Donor-Brief-Working-With-Savings-Credit-CooperativesAug-2005.pdf.

change.org. (July). Hemat APBN, Cabut Status Dekopin sebagai LNS! (Save the State Budget, Revoke Dekopin's Status as a Non-Structural Institution!). Retrieved from change.org: https://www.change.org/p/hemat-apbn-cabut-status-dekopin-sebagai-lns

CSIS. (1999). Dunia Ekuin dan Perbankan. Volume 12, Issues 7-8. Jakarta: CSIS Indonesia

Czternasty, W. (2014). The Position of Cooperatives in the New Social Economy. Management, 18(1), 488-503. https://doi.org/10.2478/manment-2014-0036.

Dunlap, K. (2018). Think Globally, Act Locally: How Communities Influence Worldwide CSR. Retrieved from solutions.yourcause.com: https://solutions.yourcause.com/thinkglobally-act-locally/

Fox, J. \&. (2013). Robust Regression. Retrieved from users.stat.umn.edu: http://users.stat. umn.edu/ -sandy/courses/8053/handouts/robust.pdf

Henderson, J. W. (1970). Area Handbook for Indonesia (39 ed., Vol. 550). Washington DC: US Government Printing Office.

Hicken, A. (2011). Clientelism. Annual Review of Political Science, 14, 289-310. https://doi. org/10.1146/annurev.polisci.031908.220508

Hopkin, J. (2006). Clientelism and Patry Politics. In R. Katz, W. Crotty, R. Katz, \& W. Crotty (Eds.), Handbook of Party Politics. Sage Publications. Sage.

Johan, J. (2002). Jatidiri Koperasi dan Nilai Ekonomi Islam untuk Keadilan Ekonomi. Jakarta: LSP2I.

Kabner, M. (2009). The Influence of the Type of Dominant Party on Democracy: A Comparison Between South Africa and Malaysia. Bonn Germany: SpringerVS.

Keefer, P. (2007). Clientelism, credibility, and the policy choices of young democracies. American Journal of Political Science, 51(4), 804-21.

Kitschelt, H. (2010). Citizen-Politician Linkage Strategies in Democracies and Investments in Party Organization. Workshop on Political Parties in the Developing World. Princeton University

Kitschelt, H., \& Wilkinson, S. (2007a). Citizen-Politician linkages: an introduction. Cambridge: Cambridge University Press.

Kitschelt, H., \& Wilkinson, S. (2007b). Patrons, Clients, and Policies: Patterns of Democratic Accountability and Political Competition. Cambridge: Cambridge Univ. Press.

Kosfeld, M. (1997). Corruption in Cooperative Society. Reuho Ekonomie Economic Series, 48. Retrieved from Reihe Okonomi Economics Series: https://www.ihs.ac.at/publications/ eco/es-48.pdf 
Kuntowijoyo. (1987). Religion, State and Social Formation in Indonesia. Southeast Asian Journal of Social Science, 15(1), 1-15.

Majee, W., \& Hoyt, A. (2011). Cooperatives and Community Development: a Perspective on the Use of Cooperatives in Development. Journal of Community Practice, 19(1), 4861. https://doi.org/10.1080/10705422.2011.550260.

Matanasi, P. (2017). Cara Legendaris ala Hatta Mengkritik Sukarno (The Legendary Way of Hatta to critisize Sukarno). Retrieved March 4, 2020, from tirto.co.id: https://tirto.id/ cara-legendaris-ala-hatta-mengkritik-sukarno-ciyQ

Mattana, P., Petroni, F., \& Rossi, S. P. (2015). A Testfor the Too-Big-to-Fail Hypothesis for European Banks during the Financial Crisis. Applied Economics, 47(3), 319-332. https://doi.org/10.1080/00036846.2014.959654

Merton, R. K. (1968). Social Theory and Social Structure. New York: Free Press.

Mhembwe, S., \& Dube, E. (2017). The Role of Cooperatives in Sustaining the Livelihoods of Rural Communities: The Case of Rural Cooperatives in Shurugwi District, Zimbambwe. Journal of Disaster Risk Studies, 9(1), 341-350. https://doi.org/10.4102/ jamba.v9i1.341

Muller, W. (2006). Party Patronage and Party Colonization of the State. In R. Katz, \& W. Crotty (Eds.), Handbook of Party Politics. Sage Publication.

Nkonki-Mandleni, B., \& Anim, F. D. (2014). Determining Factors of Support for Cooperatives in South Africa. Journal of Human Ecology, 47(2), 171-174.

Noer, D. (2012). Mohammad Hatta: Hati Hurani Bangsa Conscience of a Nation 1902-1980. Jakarta: Penerbit Djambatan Perwakilan KITLV.

Normark, P. (1996). A Role of Cooperatives in the Market Economy. Annals of Public and Cooperative Economics, 67(3), 429-439. https://doi.org/10.1111/j.1467-8292-1996. tb01914.x.

Oster, E. (2019). Unobservable Selection and Coefficient Stability: Theory and Practice. Journal of Business \& Economic Statistics, 37(2), 187-204. https://doi.org/10.1080/073 50015.2016.1227711

Pinto, A. C. (2011). Leadership, Capacity Building and Governability in Cooperative, Swedish Cooperative Center. Retrieved from http:/www.un.org/esa/socdev/social/meetings/ egm11/documents/Costa\%20Pinto-Leadership,\%20capacity\%20building.pdf

Pirie, M. (2019). George Stigler, Nobel laureate. Weblog post. Adam Smith Institute Blog.

Putra, F. (2016). Wajah Koperasi Indonesia. Homo Cooperativus, 11(011). Retrieved from https://www.academia.edu/25358885/

Richards, T. J., Klein, K. K., \& Walburger, A. (1998). Principal-Agent Relationships in Agricultural Cooperatives: an Empirical Analysis from Rural Alberta. Journal of Cooperatives, 14, 44-67.

Royer, J. (1999). Cooperative organizational strategies: A neoinstitutional digest. Journal of Cooperatives, 14, 44-67. 
Schumacher, E. F. (1973). Small is Beautiful. London: Blond \& Briggs.

Setiyono, B., \& McLeod, R. H. (2010). Civil society organisations' contribution to the anticorruption movement. Bulletin of Indonesian Economic Studies, 46(3), 347-70.

Shankar, R. (2002). How Cooperatives and their Apex Organizations can Improve their Environment at the Local, National and International Levels. Expert Group Meeting on "Supportive Environmentfor Cooperatives: A Stakeholder Dialogue on Definitions, Prerequisites and Process of Creation. The Division for Social Policy and Development, United Nations and the Government. Retrieved from https://www.un.org/esa/socdev/social/papers/ coop_shankar.pdf

Singer, M. (2009). Buying Voters with Dirty Money: the Relationship between Clientelism and Corruption. Annual Meeting American Political Science Association. Toronto.

Situmorang, J. W. (2017). Peran Dekopin dalam Pembangunan Koperasi. Jakarta: Kementerian Koperasi dan UKM RI.

Skurnik, S. (2002). The Role of Cooperative Entrepreneurship and Firms in Organizing Economic Activities -Past, Present and Future. The Finnish Journal of Business Economics, 1, 103-124.

Soesilo, N. I. (2016, July 14). Koperasi Hanya "Sokolidi" Ekonomi (Cooperative just Sticky Pillar of Economy\}. Kompas.

Somers, M. R. (2008). Genealogies of Citizenship. Cambridge: Cambridge University Press.

Soper, K. (1999). Conserving the Left: Reflections on Norberto Bobbio, Anthony Giddens and the Left-Right Distinction. Theoria: A Journal of Social and Political Theory, 94, 67-82.

Stigler, G. (1971). The Theory of Economic Regulation. Bell Journal of Economics and Management Science, 2(1), 3-21.

Subroto. (1998). Recollections of My Career,. Bulletin of Indonesian Economic Studies, 34(2), 67-92. https://doi.org/10.1080/00074919812331337340

Susilo, I. B., \& Pratamasari, A. (2018). How Did America Inspire Indonesian Revolution? Global \& Strategis, 12(2), 119-130.

The Conversation. (2019). Crime and punishment: Rural people are more punitive than citydwellers. Retrieved April 27, 2020, from https://theconversation.com/crime-andpunishment-rural-people-are-more-punitive-than-city-dwellers-127156

Thomas, B., \& Hangula, M. M. (2011). Reviewing Theory, Practices and Dynamics of Agricultural Cooperatives: Understanding cooperatives' development in Namibia. Journal of Development and Agricultural Economics, 3(16), 695-702.

Torgerson, R., Reynolds, B., \& Gray, T. (1998). Evolution of Cooperative Thought, Theory, and Purpose. Journal of Cooperatives, 13, 1-20.

Turner, B. (1986). Citizenship and Capitalism: The Debate over Reformism. London: Allen and Unwin.

US Government. (1967). Rural Development in Asia, Hearings Before the Subcommittee on Asian and Pacific Affairs. Washington DC: US Government Printing Office. 
Verheul, I., Wennekers, S., Audretsch, D., \& Thurik, R. (2001). An Eclectic Theory of Entrepreneurship. Amsterdam: Tinbergen Institute Vrije Universiteit Amsterdam.

Watanabe, Y. (2018). Think globally, act locally. Retrieved from www.undp.org: https://www. undp.org/content/undp/en/home/blog/2018/think-globally-act-locally.html

Wright, O. (2011). "Genealogies of Citizenship, Markets, Statelessness, and Right to have Rights", Cambridge University Press. Retrieved from http://www.ssc.wisc.edu/ - wright/ Published\%20writing/Comment\%20on\%20Somers \%20Genealogies\%20 of $\% 20$ Citizenship.pdf 